\title{
THE PERSPECTIVE OF SLA PRINCIPLES OF MATERIALS ANALYSIS ON A THEMATIC ENGLISH TEXTBOOK FOR SIXTH-GRADE ELEMENTARY SCHOOL
}

\author{
1Camalia Fatih Nida \\ 1Universitas Airlangga \\ Corresponding email: camalia94@gmail.com
}

\begin{abstract}
This study attempts to explain the materials of the thematic English textbook entitled "Grow with English" for sixth grade by reflecting the SLA principles. Therefore, it could be useful as a preliminary step before conducting a textbook evaluation. This article used a qualitative research method with the focus of content analysis. The writer derived the results by responding to the materials analysis proposed by Littlejohn (2011) regarding three main questions (1) what is the learner expected to do?, (2) who with? and (3) with what content?. Each question depicted certain criteria that elaborate the elements of those three questions to outline coursebook materials. Moreover, to complete the analytical of textbook task-based analysis, the writer used the concept of ten SLA principles as suggested by Ellis (2005). The results showed that gamebased tasks and consciousness-raising tasks are effective in supporting L2 acquisition since they derived both explicit and implicit knowledge. This study is limited on the scope that only focuses on a preliminary stage before conducting an in-use evaluation. The findings of this study could be a consideration and reference for EFL teachers, creators of English coursebook materials, and English coursebook policymakers, especially in Indonesia to put more attention on the importance of SLA principles in the textbook's materials that can support students' L2 acquisition.
\end{abstract}

Keywords: SLA principles, English textbook analysis, EFL, materials analysis

\section{INTRODUCTION}

A textbook or a coursebook is designed to guide language learners to enhance their communicative and linguistics competence (Sheldon, 1987). Numerous aspects of materials in a textbook have long been regarded as the pillar of 
language pedagogy (Tomlinson, 2012). The language teaching process requires textbooks to give cohesion by providing direction and to support the practice of task-based activities for students (Mares, 2003). Furthermore, Cunningsworth (1995) defined that textbooks can form an effective and quick language learning process.

From those significances and functions of textbooks, this study urges to analyse the materials of English textbooks for elementary schools, specifically sixth graders as in this stage, the students need to prepare for the next level of English learning in secondary school. In this paper, the term used is "analysis" instead of "evaluation". What it means by analysis is that it more concerns to look for what is there (Littlejohn, 2011) than evaluation which emphasizes discover whether one is seeking and if it is there, then put a value on it (McGrath, 2002).

In the Indonesian context, the pedagogical system is dynamic. The national curriculum has been formed to be the current curriculum or K-13 (Kurikulum 2013). English Language Teaching (ELT) is still unconfirmed to be a compulsory lesson at elementary school levels; however, many elementary schools in Indonesia have implemented ELT as a local subject. Hence, it is necessary to know how materials depicted in English textbooks for sixthgrade students could conclude six years of L2 learning. This stage of analysis can be a preliminary step before doing a materials evaluation. According to that, this study tried to reveal some suitable methods in the textbook to provide an effective L2 learning process for students and teachers. Derived from Nikolov \& Djigunović (2006), the curriculum of primary EFL education needs SLA practices to be constructed to support both affective and cognitive developments. Furthermore, SLA practices were crucial to assist motivation on learning a language over six years in primary schools (Nakata, 2009).

This study aimed to arrange the outlines of the English textbook "Grow with English" for sixth grade by using SLA principles and to reveal how the English textbook content reflected second language acquisition principles. This textbook was published by a local publisher named Penerbit Erlangga and written by Mukarto, Sujatmiko, Josephine S.M, and Widya Kiswara. "Grow with English" is an English textbook for sixth-grade elementary students and has been used in several schools in Indonesia. The writer particularly chose this book because the publisher, Penerbit Erlangga, is a trusted publisher that has been chosen by education authorities as a supplementary book for teachers and students. Moreover, this brand consecutively achieved the top brand in the category of education books (detik.com, 2021). Furthermore, Aydawati (2005) stated that local coursebooks in Indonesia are too focus on reading; it neglects demands in the listening section and discourses of native-like speaking. 
Second language acquisition can be used to give insights regarding some strengths and weaknesses as the development of language learning materials (Cook, 1998). It was noted from (Ellis, 1997) that SLA principles were presented to define and criticize materials design features by analyzing materials that can be categorized "in harmony with how learners learn". Later, Ellis (2005) suggested ten principles of SLA to help researchers sort out the needs of the L2 learning process. Those principles paid attention to instruction's role to guide learners in L2 acquisition from the task-centered study. Principle 1 encompassed the instruction's necessity to confirm learners' development in the proper repertoire (fluency) and competency-based on grammatical rules. Principle 2 emphasized the meaning-focused needs be applied in the learning process. Principle 3 represented the importance of focus-on-form. Principle 4 related to the equal importance of implicit (acquisition) and explicit (learning) knowledge of L2 development in the L2 learning process. Principle 5 reckoned the learners' built-in syllabus which derived from Krashen that task-based approach was not trying to adopt linguistic content in the lessons assures that learners are ready to obtain certain target features and centralize explicit knowledge instead of implicit knowledge. Principle 6 referred to extensive L2 input that is necessary to gain effective learning. Meanwhile, principle 7 took an account of the importance of output. Principle 8 related to L2 proficiency that intertwines with interaction in the learning process for L2 learners. Principle 9 ensured that individuals are different when acquiring L2; thus, the motivation and capability of learners may require different learning styles which are beyond most teachers' ability. Finally, principles 10 considered that the assessment aspect is crucial to measure L2 proficiency freely or in a controlled way.

Materials analysis in English textbooks in language teaching becomes the framework for this research. Three questions proposed by (Littlejohn, 2011) are the tools to break down the materials. To identify each element in the materials, Littlejohn divided them into tasks analysis: what is the learner expected to do? Who with and with what content?. Furthermore, Littlejohn explained that those three questions were suitable and comprehensible for analysing language acquisition since they would break down the constituent of the tasks to reveal which tasks matched learners' language input. In addition, the three main aspects mentioned earlier could construct the concept about how tasks were able to process which way to go for learners and teachers, with whom the participation in the classroom concerning learners must work, and about what content the learners had to concentrate on.

Even though studies focused on English textbooks had previously been conducted (Dang \& Seals, 2018; Ko, 2014; Mukundan et al., 2011), the majority of their purposes were mainly to evaluate the content. Mukundan et al., (2011) explained the evaluation of textbook with the purpose to help students 
and EFL teachers in Malaysia to get positive change. It evaluated the textbook to be more reliable and practical by using a checklist. Moreover, the evaluation process in the English textbooks had been done by Dang \& Seals (2018). They evaluated the textbook concerning sociolinguistics aspects in Vietnam such as teaching methods, bilingualism, intercultural communication, and variations of language in the textbooks which had been proposed by Vietnam's Ministry of Education. In addition, Ko (2014) investigated the design of English textbooks and suggested that it could be a more modern design to suit communicative grammar learning. Ko criticized the textbooks did not reflect communicative language teaching principles.

Meanwhile, in Indonesia, some studies about English textbook evaluation had been done by focusing on EFL textbook evaluation of high school English textbooks (Ayu \& Indrawati, 2019). They tried to find out the task distribution and its correlation with the objectives of curriculum 13 of the book. As a result, there were some points that did not match the claim. Another article about English textbook evaluation had been done by (Anshar et al., 2014). The article tried to depict reflective evaluation with more emphasis on vocabulary teaching and learning as a language aspect of Buku Sekolah Elektronik (BSE) or English Electronic Books for junior high school which published by Indonesian government. The study revealed that from several aspects including the criteria of English textbooks in terms of physical appearance and content of the textbooks, Anshar mentioned that both textbooks (English Electronic Books (BSE) 'Textbook (T1)' and 'Textbook 2 (T2)' needed some improvements on how to design the activities and to add some proper supporting aids for the teacher.

The research notion of English textbooks designed accordingly to SLA principles is still limited. Hence, this study offers a perspective in analysing materials of English textbooks in elementary school by using SLA principles especially for L2 learners in the early stage. This analysis was a preliminary step before conducting the evaluation. Therefore, this study came up with the research question: (1) to what extent does the thematic English course "Grow with English" for sixth-grade elementary students apply the SLA principles? (2) what kind of tasks do SLA principles reflect?

\section{METHODS}

\section{Subject}

This research used the English textbook for sixth graders namely "Grow with English" published by Erlangga publisher in 2017. This book was confirmed to be essential since most public elementary schools in Indonesia applied this book as a supplementary book. This study used a qualitative research method that focused on content analysis. Bogdan (2003) stated that descriptive is in qualitative research in which the data are taken from documents, audio or 
video recordings, transcripts, pictures, words, etc. Because this paper dealt with materials analysis, it derived the descriptive qualitative research design.

This study adopted the framework of three 'level' analyses from Littlejohn (2011). Regarding that, level 2 mentioned three questions to break down the materials analysis which illustrated a deeper level of analysis of what the users required to gain what the importance of materials' aspects is. At this level, it was needed to carry deductions of what exactly teacher and student needed to do. The three questions such as What is the learner expected to do? Who with? and With what content? were used to divide the materials into the elements of the tasks. The purpose was to create an exact meaning of what a 'task' is. Meanwhile, level 1 explained an objective description of what is there, this level outlined subjective selections of materials' objective facts e.g. description statements, materials' physical aspects, and instructional sections of the main steps. The general summary of level 1 and level 2 was in level 3. it carried materials' underlying principles and concluded the roles designed for teachers and students.

\section{Data Analysis Procedures}

The writer selected one chapter of the materials in the textbook, the chosen unit was "Unit 1" with a theme named "I Had a Great Holiday". Since the chapters in the textbook consisted similar set of materials, the writer chose any chapter randomly as a sample that represented the whole contents of the textbook.

First, the writer separated a set of book's contents with the tasks per chapter following from Littlejohn (2011). In many cases, a set of tasks may coordinate into one numbering. For example: "read the text and answer the following questions". It was found that there were 13 tasks in chapter 1 . Then, the 13 tasks were put into tables and analysed using a task analysis schedule derived from Littlejohn (2011). Second, the writer used three main questions from Littlejohn to identify where the boundaries of the task occurred and to acknowledge the process, participation, and content of the task materials.

Next, the writer managed to use features to elaborate the three questions with the purpose to reveal the best method in language learning that was reflected in the perspective of SLA principles proposed by Ellis (2005). It was natural that materials' designers had an assumption about teachers' and students' roles in the classroom that reflected in the textbook, consequently, the writer used SLA principles to know thoroughly which certain task activity that could help teachers and students to achieve effective language learning process.

\section{FINDINGS}


The data were analysed using materials analysis proposed by Littlejohn (2011) related to three main questions for analysing the tasks. The first question_was What is the learner expected to do?. This question was concerned with the process of learning which emphasized the focus on the detail of what actually the learners expected to do from the tasks given. This question consisted of three branches such as turn-take, focus, and mental operation. Turn-take covered the class activities, what students' role in the classroom discourse that they were expected to get; it could be they were expected to initiate language, to respond or they did not need to do any actions, for instance: listening to teacher's explanation. Focus related to form of tasks; whether students were asked to do practice, to do comprehension exercises, or to make some reports. The next section was a mental operation, it required mental process when doing the tasks. For example, in the tasks' description, students were demanded to follow sequences of tasks in the details of materials; it could be making some repetition, reproducing sounds, interpreting the meaning of language, writing a text, and so on.

The second question suggested by Littlejohn (2011) was Who with? This section referred to with whom the students work, and if they are in pairs, groups, or individuals. Finally, the last question was with what content? The nature of content related to input to be covered in the tasks and obtained output in what learners expected to do. Input for learners could be written or spoken tasks, pictures, sequences, stories, and so on. The expected output for learners could be giving respond, filling the blank, answering questions, matching items, circling the pictures, singing a song, and so on. In the content, it looked for the nature and source of the materials. Nature meant that whether the tasks include grammar explanations about vocabularies or the use of certain expressions. Source related to the beginning of how the tasks presented. It could be from the text or dialog in the materials, from teachers' presentation, or from students' presentation from their research.

English coursebook "Grow with English" consists of six units and 12 to 13 tasks per unit and in short, there are 72 tasks identified. Although each unit has a different theme, the pattern and formula of task activities and descriptions are similar. Therefore, the writer chose one unit randomly to investigate thoroughly using tasks analysis schedule as presented in Table 1, 2, 3, 4, and 5. Unit 1 was chosen with the theme "I Had a Great Holiday". Task activities that reflected SLA principles were identified with plus (+) sign, minus (-) sign when it was otherwise, and cross (x) sign when none of them presented. 
The Perspective of SLA Principles of Materials Analysis on a Thematic English Textbook...

Table 1: Turn-take Tasks Analysis of "Grow with English" by Penerbit Erlangga Using Task Analysis Schedule derived from Littlejohn (2011)

\begin{tabular}{|c|c|c|c|c|c|c|c|c|c|c|c|c|c|}
\hline \multirow{2}{*}{\multicolumn{14}{|c|}{$\begin{array}{l}\text { Task number } \\
\text { (1) What is the } \\
\text { learner expected to } \\
\text { do? }\end{array}$}} \\
\hline & & & & & & & & & & & & & \\
\hline \multicolumn{14}{|l|}{ A. TURN-TAKE } \\
\hline $\begin{array}{l}\text { a. Initiate language } \\
\text { - E.g., write a } \\
\text { text according } \\
\text { to lessons that } \\
\text { are taught, } \\
\text { make } \\
\text { questions, text, } \\
\text { or list. }\end{array}$ & $x$ & $x$ & $x$ & $x$ & + & $x$ & $x$ & + & $x$ & + & $x$ & $x$ & $x$ \\
\hline $\begin{array}{l}\text { b. Produce response } \\
\text { (scripted) } \\
\text { - E.g., answering } \\
\text { direct } \\
\text { questions, } \\
\text { comprehend } \\
\text { questions, drills }\end{array}$ & + & - & $x$ & $x$ & + & $x$ & $x$ & + & $x$ & + & $x$ & $x$ & $x$ \\
\hline $\begin{array}{l}\text { c. Not required action } \\
\text { or no direct } \\
\text { interactive activity } \\
\text { - E.g., read, listen } \\
\text { to the } \\
\text { explanation }\end{array}$ & $x$ & - & $x$ & $x$ & $x$ & - & $x$ & $x$ & $x$ & $x$ & $x$ & $x$ & $x$ \\
\hline Total value & +1 & -2 & 0 & 0 & +2 & -1 & 0 & +2 & 0 & +2 & 0 & 0 & 0 \\
\hline
\end{tabular}

Table 1 presents one of three questions proposed by Littlejohn "What is the learner expected to do?". In the turn-take section, almost all coursebook content did not push students to initiate L 2 by their own words, except task 5 (produce dialog) and task 10 (game-based tasks). In game-based tasks and practice dialog, students were asked to produce L2 expressions from pictures shown. The rest of the unit 1 task activity merely followed directions and produce a scripted response. Therefore, $(x)$ signs are shown frequently. Instructions were needed to provide opportunities for learners to initiate language without neglecting meaning-based and focus on form as depicted in SLA principles from an early age. 
In the elements of produce response, almost all task activities present a good approach to trigger students' attention to understand the context of the tasks. Meanwhile, one activity in task number 2 that only conducted mechanical drills which had a probability that the input of L2 learning did not affect the process; it is indicated by minus (-) sign. In contrast with task number 2, tasks number 8 and 10 emphasized pushing students' ability to gain knowledge from the content materials such as practicing dialog, walking around, and asking friends about their holiday. No required action sessions are depicted in the coursebook several times. However, each task activity consisted of two performances, for example, listen and do, and listen and talk. When the task description consisted of two points, it was considered that action was required. Furthermore, task-based analysis in focus sessions is presented in Table 2.

Table 2. Focus Tasks Analysis of "Grow with English" by Penerbit Erlangga Using Task Analysis Schedule derived from Littlejohn (2011)

\begin{tabular}{|c|c|c|c|c|c|c|c|c|c|c|c|c|c|}
\hline Task number & 1 & 2 & 3 & 4 & 5 & 6 & 7 & 8 & 9 & 10 & 11 & 12 & 13 \\
\hline \multicolumn{14}{|l|}{ B. FOCUS } \\
\hline $\begin{array}{l}\text { a. Language system } \\
\text { - E.g. practice } \\
\text { patterns or } \\
\text { forms of } \\
\text { language } \\
\text { (adjectives, } \\
\text { expressions, } \\
\text { etc.) }\end{array}$ & $x$ & + & + & $x$ & + & + & + & $x$ & $x$ & + & + & $x$ & + \\
\hline $\begin{array}{l}\text { b. Meaning } \\
\text { - E.g. tasks } \\
\text { comprehension }\end{array}$ & + & + & + & $x$ & + & $x$ & + & $x$ & $x$ & $x$ & + & + & + \\
\hline $\begin{array}{l}\text { c. Meaning/form } \\
\text { relationship/system } \\
\text { - E.g. activity } \\
\text { includes } \\
\text { consciousness } \\
\text { learning; fill the } \\
\text { blanks }\end{array}$ & $x$ & + & + & $x$ & $X$ & $x$ & + & + & $x$ & + & + & + & + \\
\hline
\end{tabular}

\begin{tabular}{llllllllllllll}
\hline Total value & +1 & +2 & +3 & 0 & +2 & 0 & +3 & +1 & 0 & +2 & +3 & +2 & +3 \\
\hline
\end{tabular}

Table 2 shows the analysis of meaning-centred materials, it indicates whether a certain type of task activity reflects SLA principles or not. 
The Perspective of SLA Principles of Materials Analysis on a Thematic English Textbook...

Regarding learners' benefit when doing the tasks, the results indicated that most tasks triggered learners' attention which affected their motivation to enhance L2 performance. In language practice elements, there were 8 areas that are considered can enhance students' L2 comprehension because they included an activity where students could get involved to practice language patterns and forms. Other forms of meaning comprehensions were depicted in tasks in which learning activity adopted consciousness-raising performances such as fill in the blanks, match correct answers, and so on. Align with SLA principles that emphasized meaning-based, the result of this section of schedule task analysis was proper enough to support learners' learning process.

Table 3. Mental Operation Tasks Analysis of "Grow with English" by Penerbit Erlangga Using Task Analysis Schedule derived from Littlejohn (2011)

\begin{tabular}{|c|c|c|c|c|c|c|c|c|c|c|c|c|c|}
\hline Task number & 1 & 2 & 3 & 4 & 5 & 6 & 7 & 8 & 9 & 10 & 11 & 12 & 13 \\
\hline $\begin{array}{l}\text { C. MENTAL } \\
\text { OPERATION }\end{array}$ & & & & & & & & & & & & & \\
\hline a. Express own ideas & $x$ & $x$ & $x$ & $X$ & $X$ & $x$ & $x$ & + & $x$ & $x$ & $x$ & $x$ & $x$ \\
\hline $\begin{array}{l}\text { b. Mechanical drills } \\
\text { - E.g. repeating } \\
\text { what is heard, } \\
\text { listening } \\
\text { practice }\end{array}$ & $x$ & - & $x$ & - & - & - & $x$ & + & $\mathrm{x}$ & $x$ & $x$ & $x$ & $x$ \\
\hline $\begin{array}{l}\text { c. Meaningful drills } \\
\text { - E.g. answering } \\
\text { relatable } \\
\text { questions } \\
\text { (unscripted) }\end{array}$ & $x$ & + & + & + & $X$ & $x$ & $x$ & + & $x$ & + & + & $x$ & $x$ \\
\hline $\begin{array}{l}\text { d. Hypothesize } \\
\text { - E.g. guess the } \\
\text { meaning }\end{array}$ & $x$ & $x$ & + & $X$ & + & $x$ & + & $x$ & + & + & + & + & + \\
\hline $\begin{array}{l}\text { e. Apply general } \\
\text { knowledge } \\
\text { - E.g. select the } \\
\text { correct version; } \\
\text { true/false }\end{array}$ & $x$ & + & + & $x$ & + & $x$ & + & $x$ & $x$ & + & + & + & + \\
\hline Total value & 0 & +1 & +3 & 0 & +1 & $\begin{array}{l}- \\
1\end{array}$ & +2 & +3 & +1 & +3 & +3 & +2 & +2 \\
\hline
\end{tabular}

Mental operation related to learners' mentality when processing L2 information. Most mental operation aspects had been delivered clearly. There 
were four elements that could sort out learners' needs such as expressing own ideas, conducting mechanical and meaningful drills, and applying general knowledge. It was necessary to apply those four aspects to increase students' ability in performing L2, but apparently in the coursebook, there was one thing which was left out and not being able to be applied to express students' idea. Meanwhile, this aspect was crucial to practice L2 comprehension. Students needed to produce language and express ideas so that teachers could measure the output of L2 learning. Furthermore, mechanical drills deduced input because it only focused on repetition without knowing the meaning of expressions or sentences which reflect SLA principles; hence minus (-) signs are shown. Other aspects such as meaningful drills, hypothesizing and applying for general knowledge supported L2 learning in task activities.

Table 4. Participant Involved Task Analysis

\begin{tabular}{|c|c|c|c|c|c|c|c|c|c|c|c|c|c|}
\hline \multirow{2}{*}{\multicolumn{14}{|c|}{$\begin{array}{l}\text { Task number } \\
\text { (2) Who with? }\end{array}$}} \\
\hline & & & & & & & & & & & & & \\
\hline $\begin{array}{l}\text { A. Learners work } \\
\text { individually }\end{array}$ & $x$ & $x$ & + & $x$ & $x$ & $x$ & + & $x$ & + & + & + & + & + \\
\hline $\begin{array}{l}\text { B. Learners } \\
\text { pair/group work }\end{array}$ & $x$ & $x$ & $x$ & $x$ & + & $x$ & $x$ & $x$ & $x$ & $x$ & $x$ & $x$ & $x$ \\
\hline $\begin{array}{l}\text { C. Teacher to } \\
\text { students } \\
\text { - E.g. teacher } \\
\text { performs } \\
\text { question and } \\
\text { answer } \\
\text { sections }\end{array}$ & + & + & $x$ & + & $x$ & + & + & + & + & + & + & + & + \\
\hline Total value & +1 & +1 & +1 & +1 & +1 & +1 & +2 & +1 & +2 & +2 & +2 & +2 & +2 \\
\hline
\end{tabular}

Regarding participants in the learning process, the second question proposed by Littlejohn had been used to outline with whom the L2 learners conduct the L2 learning process. Table 4 presents the result of task analysis concerning the participant structure. In the coursebook, it had been found that most of the time, learners worked individually, and the teacher instructed students to do task activities. Although these activities could be beneficial for L2 learners, they did not maximize the learning process. Pair and group activities had been neglected frequently unless for one particular activity in task number 5 where the students were asked to perform dialog and asked one another about their holiday. Pair and group work activities had a high potential for interaction and negotiation of meaning in the L2 learning process. Accordingly, pair and group work activities would be better for 
The Perspective of SLA Principles of Materials Analysis on a Thematic English Textbook...

engaging L2 learners to exchange ideas and enhance materials comprehension when English coursebooks are more focused on pair or group work in task activity. It is in line with what suggested by Ellis about SLA principles which related to the importance of interaction in learning process to boost L2 proficiency.

Table 5. Content Materials Task Analysis

\begin{tabular}{|c|c|c|c|c|c|c|c|c|c|c|c|c|c|}
\hline \multirow{2}{*}{\multicolumn{14}{|c|}{$\begin{array}{l}\text { Task number } \\
\text { (3) With what } \\
\text { content? }\end{array}$}} \\
\hline & & & & & & & & & & & & & \\
\hline \multicolumn{14}{|l|}{ A. Form } \\
\hline $\begin{array}{l}\text { (a) Learner's input } \\
\text { - E.g., visual } \\
\text { (pictures, } \\
\text { game), } \\
\text { written } \\
\text { (coherent } \\
\text { text), aural } \\
\text { (listening } \\
\text { sessions) }\end{array}$ & + & + & + & + & + & + & + & + & + & + & + & + & + \\
\hline $\begin{array}{l}\text { (b) Learners } \\
\text { expected output } \\
\text { - E.g., match } \\
\text { items, tick the } \\
\text { correct } \\
\text { answer, } \\
\text { true/false, fill } \\
\text { in the blanks, } \\
\text { read } \\
\text { connected } \\
\text { sentences }\end{array}$ & - & + & + & - & + & - & + & $x$ & + & + & + & + & + \\
\hline
\end{tabular}

B. Source

\begin{tabular}{|c|c|c|c|c|c|c|c|c|c|c|c|c|c|}
\hline $\begin{array}{l}\text { (a) Dialog/text } \\
\text { materials }\end{array}$ & + & + & + & + & + & + & + & + & + & + & + & + & + \\
\hline $\begin{array}{l}\text { (b) Learners } \\
\text { - E.g., doing } \\
\text { presentation }\end{array}$ & $x$ & $x$ & $x$ & $x$ & $x$ & $x$ & $x$ & $x$ & $x$ & $x$ & $x$ & $x$ & $x$ \\
\hline $\begin{array}{l}\text { (c) Teacher } \\
\text { - E.g., facilitate } \\
\text { tasks } \\
\text { instruction }\end{array}$ & + & + & + & + & + & + & + & + & + & + & + & + & + \\
\hline
\end{tabular}

C. Nature

\begin{tabular}{llllllllllllll} 
(a) Non-fiction & $\mathrm{x}$ & $\mathrm{x}$ & $\mathrm{x}$ & $\mathrm{x}$ & $\mathrm{x}$ & $\mathrm{x}$ & $\mathrm{x}$ & $\mathrm{x}$ & $\mathrm{x}$ & $\mathrm{x}$ & $\mathrm{x}$ & $\mathrm{x}$ & $\mathrm{x}$ \\
\hline
\end{tabular} 


\begin{tabular}{llllllllllllll}
\hline Task number & $\mathbf{1}$ & $\mathbf{2}$ & $\mathbf{3}$ & $\mathbf{4}$ & $\mathbf{5}$ & $\mathbf{6}$ & $\mathbf{7}$ & $\mathbf{8}$ & $\mathbf{9}$ & $\mathbf{1 0}$ & $\mathbf{1 1}$ & $\mathbf{1 2}$ & $\mathbf{1 3}$ \\
\hline (b) Fiction & - & - & - & - & - & $\mathrm{x}$ & - & - & - & $\mathrm{x}$ & - & - & - \\
\hline (c) Game/chant & $\mathrm{x}$ & $\mathrm{x}$ & $\mathrm{x}$ & - & $\mathrm{x}$ & - & $\mathrm{x}$ & $\mathrm{x}$ & $\mathrm{x}$ & + & $\mathrm{x}$ & $\mathrm{x}$ & $\mathrm{x}$ \\
\hline (d) Song & $\mathrm{x}$ & $\mathrm{x}$ & $\mathrm{x}$ & $\mathrm{x}$ & $\mathrm{x}$ & $\mathrm{x}$ & $\mathrm{x}$ & + & $\mathrm{x}$ & $\mathrm{x}$ & $\mathrm{x}$ & $\mathrm{x}$ & $\mathrm{x}$ \\
\hline Total value & +2 & +3 & +3 & +1 & +3 & +2 & +3 & +4 & +3 & +5 & +3 & +3 & +3 \\
\hline
\end{tabular}

Table 5 presents content analysis which more emphasized input and output for learners in the L2 learning process. A complete task facility was a pervasive input to learn L2. Overall, the task in each unit consisted of activities that could help students absorb the content of the materials. However, the expected output was lower than the input. The expected output was limited due to the type of required output in the controlled and dictated tasks. Learners' L2 acquisition would get maximum output if extensive input facilitated learners to perform L2 practice more flexibly. The nature element presented that everything still in control except the fiction aspect that had a probability to deduce SLA principles, coursebooks should involve more task activities about learners' personal experience (non-fiction) to enhance their L2 learning motivation.

\section{Summary of Result Analysis}

Table 6. Final Result Analysis from Task Analysis Sheet

\begin{tabular}{lccccccccccccc}
\hline $\begin{array}{l}\text { Task } \\
\text { number }\end{array}$ & $\mathbf{1}$ & $\mathbf{2}$ & $\mathbf{3}$ & $\mathbf{4}$ & $\mathbf{5}$ & $\mathbf{6}$ & $\mathbf{7}$ & $\mathbf{8}$ & $\mathbf{9}$ & $\mathbf{1 0}$ & $\mathbf{1 1}$ & $\mathbf{1 2}$ & $\mathbf{1 3}$ \\
\hline $\begin{array}{l}(1) \text { What } \\
\text { is the }\end{array}$ & +2 & +1 & +6 & 0 & +5 & -2 & +5 & +6 & +1 & +7 & +6 & +4 & +5 \\
$\begin{array}{l}\text { learner } \\
\text { expected } \\
\text { to do? }\end{array}$ & & & & & & & & & & & & & \\
\hline $\begin{array}{l}(2) \text { Who } \\
\text { with? }\end{array}$ & +1 & +1 & +1 & +1 & +1 & +1 & +2 & +1 & +2 & +2 & +2 & +2 & +2 \\
$\begin{array}{l}\text { (3) With } \\
\text { what }\end{array}$ & +2 & +3 & +3 & +1 & +3 & +2 & +3 & +4 & +3 & +5 & +3 & +3 & +3 \\
content? & & & & & & & & & & & & & \\
\hline $\begin{array}{l}\text { Total } \\
\text { value }\end{array}$ & 5 & 5 & 10 & 2 & 9 & 1 & 10 & 11 & 6 & 14 & 11 & 9 & 10 \\
\hline
\end{tabular}

Table 7. Sample of Content Presented in the Textbook

\begin{tabular}{cll}
$\begin{array}{c}\text { Task } \\
\text { number }\end{array}$ & \multicolumn{1}{c}{$\begin{array}{c}\text { Instruction and task } \\
\text { description }\end{array}$} & \multicolumn{1}{c}{ Materials } \\
\hline 1 & Look and answer. & 1. Whose family is it? \\
& & 2. Where are they? \\
& & 3. What are the girls wearing? \\
\hline
\end{tabular}


The Perspective of SLA Principles of Materials Analysis on a Thematic English Textbook...

\begin{tabular}{|c|c|c|}
\hline $\begin{array}{c}\text { Task } \\
\text { number }\end{array}$ & $\begin{array}{c}\text { Instruction and task } \\
\text { description }\end{array}$ & Materials \\
\hline & $\begin{array}{l}\text { (teacher points out the picture } \\
\text { of Dana's family and asks } \\
\text { students to answer questions) }\end{array}$ & 4. What is the man holding? \\
\hline 2 & $\begin{array}{l}\text { Read aloud. } \\
\text { (teacher asks students to read } \\
\text { aloud to the text after they } \\
\text { listen to the recording about } \\
\text { the text and focus to students' } \\
\text { pronunciation) }\end{array}$ & $\begin{array}{l}\text { a. It was fun. } \\
\text { I had a fun holiday. } \\
\text { b. It was tiring. } \\
\text { I had a tiring holiday. } \\
\text { c. It was great. } \\
\text { I had a great holiday. } \\
\text { d. It was boring. } \\
\text { I had a boring holiday. }\end{array}$ \\
\hline 3 & $\begin{array}{l}\text { Listen and draw lines. } \\
\text { (teacher points out the } \\
\text { pictures and asks students to } \\
\text { read the first sentence. After } \\
\text { that, the students listen to the } \\
\text { recording and match the } \\
\text { pictures with the sentences) }\end{array}$ & $\begin{array}{l}\text { 1. (a picture of a kid who is smiling) } \\
\text { 2. (a picture of a kid who is tired) } \\
\text { 3. (a picture of a kid who is smiling) } \\
\text { a. It was awesome. } \\
\text { b. It was great. } \\
\text { c. It was tiring. }\end{array}$ \\
\hline 4 & $\begin{array}{l}\text { Say a chant. } \\
\text { (teacher guides students to } \\
\text { repeat a chant) }\end{array}$ & $\begin{array}{l}\text { Really? } \\
\text { It was great! } \\
\text { Really? } \\
\text { Yes, it was. } \\
\text { It was tiring. } \\
\text { Really? } \\
\text { Yes, it was. } \\
\text { It was fun! } \\
\text { Really? } \\
\text { Yes, it was. } \\
\text { It was boring. } \\
\text { Really? } \\
\text { Yes, it was. }\end{array}$ \\
\hline 5 & $\begin{array}{l}\text { Listen and talk. } \\
\text { (teacher gives instructions } \\
\text { and asks students to practice } \\
\text { the dialog. After that, students } \\
\text { are asked to walk around the } \\
\text { class and ask friends to make } \\
\text { dialog about their holiday. } \\
\text { The theme of the dialog can } \\
\text { vary) }\end{array}$ & $\begin{array}{l}\text { Nurul: Hi, Seta. How was your } \\
\text { holiday? } \\
\text { Seta: It was awesome. How was } \\
\text { your holiday, Nurul? Was it great? } \\
\text { Nurul: Not really. I had a tiring } \\
\text { holiday. } \\
\text { a. boring } \\
\text { b. tiring } \\
\text { c. great }\end{array}$ \\
\hline
\end{tabular}




\begin{tabular}{|c|c|c|}
\hline $\begin{array}{c}\text { Task } \\
\text { number }\end{array}$ & $\begin{array}{c}\text { Instruction and task } \\
\text { description }\end{array}$ & Materials \\
\hline & & d. fun \\
\hline 6 & $\begin{array}{l}\text { Listen and do. } \\
\text { (make a chant about the } \\
\text { expressions) }\end{array}$ & $\begin{array}{l}\text { a. Scrub the floor. } \\
\text { b. Climb a tree. } \\
\text { c. Dust the sofa. } \\
\text { d. Wash the car. }\end{array}$ \\
\hline 7 & $\begin{array}{l}\text { Listen and tick }(\sqrt{ }) \\
\text { (teacher plays the recording } \\
\text { and asks students to tick the } \\
\text { correct choice that relates to } \\
\text { the questions) }\end{array}$ & $\begin{array}{l}\text { 1. How was Seta's last holiday? } \\
\text { a. (a picture of Seta is dancing) } \\
\text { b. (a picture of Seta is boring) } \\
\text { c. (a picture of Seta is ill) } \\
\text { 2. How was Rafa's family's holiday? } \\
\text { a. (a picture of Rafa's family is } \\
\text { doing exercise) } \\
\text { b. (a picture of Rafa's family is } \\
\text { watching TV) } \\
\text { c. (a picture of Rafa's family is on a } \\
\text { trip by car) }\end{array}$ \\
\hline 8 & $\begin{array}{l}\text { Sing a song. } \\
\text { (first, teacher asks students to } \\
\text { sing a song together. Then, } \\
\text { teacher asks about students' } \\
\text { holiday one by one, the } \\
\text { students should answer and } \\
\text { initiate language using } \\
\text { rhymes of the song) }\end{array}$ & $\begin{array}{c}\text { Last Holiday } \\
\text { (Sung to the tune of 'Here We Go } \\
\text { 'Round the Mulberry Bush') } \\
\text { I travelled around and I played } \\
\text { football. } \\
\text { Last holiday, last holiday } \\
\text { I climbed a tree and I learned to } \\
\text { swim. } \\
\text { My holiday was fun. } \\
\text { I stayed at home and I cleaned my } \\
\text { house. } \\
\text { Last holiday, last holiday } \\
\text { I washed the car and I scrubbed the } \\
\text { floor. } \\
\text { My holiday was tiring }\end{array}$ \\
\hline 9 & $\begin{array}{l}\text { Listen and write. } \\
\text { (teacher plays the recording } \\
\text { and gives instructions for } \\
\text { students to answer the } \\
\text { questions) }\end{array}$ & $\begin{array}{l}\text { 1. What is the boy's name? } \\
\text { 2. How many toy cars did Dana } \\
\text { give Tigor? } \\
\text { 3. When did Dana go to Malang? } \\
\text { 4. How did she visit there? } \\
\text { 5. What did she visit there? }\end{array}$ \\
\hline
\end{tabular}


The Perspective of SLA Principles of Materials Analysis on a Thematic English Textbook...

\begin{tabular}{|c|c|c|}
\hline $\begin{array}{c}\text { Task } \\
\text { number }\end{array}$ & $\begin{array}{c}\text { Instruction and task } \\
\text { description }\end{array}$ & Materials \\
\hline 10 & $\begin{array}{l}\text { Play a game. } \\
\text { (teacher invites students to do } \\
\text { a board game. Then, teacher } \\
\text { explains the rules and points } \\
\text { out each picture. Students do } \\
\text { rock-scissor-paper and } \\
\text { proceed the game) }\end{array}$ & $\begin{array}{l}\text { Start }>\text { picture } 1 \text { (a boy is cleaning a } \\
\text { chair) }>\text { picture } 2 \text { (a family is going } \\
\text { to the trip by car) }>\text { picture } 3 \\
\text { (instruction to move } 4 \text { steps } \\
\text { forward)... }\end{array}$ \\
\hline 11 & $\begin{array}{l}\text { Read and draw lines. } \\
\text { (teacher explains the task and } \\
\text { asks students to match the } \\
\text { sentences above as a cause } \\
\text { and sentences below as an } \\
\text { effect) }\end{array}$ & $\begin{array}{l}\text { 1. I forgot my umbrella. } \\
\text { 2. There were so many visitors. } \\
\text { 3. It was raining hard. } \\
\text { 4. Made was not well. } \\
\text { 5. Seta was not careful. } \\
\text { 6. Meilin did not have breakfast. } \\
\text { 7. We did not get train tickets. } \\
\text { a. We stayed home and watched } \\
\text { TV. } \\
\text { b. He did not go to school. } \\
\text { c. The museum was very crowded. } \\
\text { d. She had a stomachache. } \\
\text { e. We travelled by car. } \\
\text { f. I got wet. } \\
\text { g. He hurt his finger. }\end{array}$ \\
\hline 12 & $\begin{array}{l}\text { Read and write 'yes' or 'no' } \\
\text { (teacher gives instructions } \\
\text { about the tasks and does } \\
\text { example for the notices with } \\
\text { yes/no answers. Then, } \\
\text { students can do the rest of the } \\
\text { tasks) }\end{array}$ & $\begin{array}{l}\text { Notice } 1 \\
\text { Batu Transport Museum } \\
\text { Opening Hours: } \\
\text { Ticket counters: } \\
11.00 \text { am - } 7.30 \text { pm } \\
\text { Visiting Hours: } \\
12.00 \text { - } 8.00 \text { pm } \\
\text { Notice } 2 \\
\text { Monday - Thursday } 10.00-18.00 \\
\text { Friday } 11.00 \text { - } 18.00 \\
\text { Saturday - Sunday } 10.00-18.00 \\
\text { Last admission } 17.15 \\
\text { Closed: December } 24 \text { to } 26 \\
\text { Yes or No } \\
\text { 1. The transport Museum is in Batu. }\end{array}$ \\
\hline
\end{tabular}




\begin{tabular}{|c|c|c|}
\hline $\begin{array}{c}\text { Task } \\
\text { number }\end{array}$ & $\begin{array}{l}\text { Instruction and task } \\
\text { description }\end{array}$ & Materials \\
\hline & & $\begin{array}{l}\text { 2. The ticket counters open at } 12.00 \text {. } \\
\text { 3. You may enter the museum after } \\
17.15 \text {. }\end{array}$ \\
\hline 13 & $\begin{array}{l}\text { Read and write. } \\
\text { (teacher asks students to read } \\
\text { the text. Then, teacher gives } \\
\text { example to complete } \\
\text { sentences number } 1 . \text { Students } \\
\text { may do the rest of the tasks) }\end{array}$ & $\begin{array}{l}\text { a. car } \\
\text { b. went } \\
\text { c. tickets } \\
\text { Last holiday my friend and I (1) .... } \\
\text { to Malang. We wanted to go by } \\
\text { train but we did not get the (2) ..... } \\
\text { so, we travelled by (3) ...... }\end{array}$ \\
\hline
\end{tabular}

Overall result analysis shown in Table 6 informed the certain pattern to signify task-based analysis with SLA principles approach. Task number 10 had the highest value to direct student attention in performing the L2 learning process. Task number 10 was game-based learning that consisted of both explicit and implicit learning. It indicated that not only students could have fun during the acquisition process, but they also conducted explicit learning. For example, they would remember certain expressions related to adjectives lessons they attempted to acquire in the previous lessons. Moreover, the total values are even for task number 3 (choose the correct expressions), 5 (produce dialog), 7 (choose the correct answer), 8 (sing a song that urges them to initiate language in this activity based on their own experience), 11 (choose the correct answer), 12 (true/false) and 13 (fill in the blank). It means several types of tasks are proper enough to support students' L2 learning process. Besides, task number 6 that asked students to make a chant session had the lowest score in this analysis. For sixth-grade elementary students, this kind of task lacks in absorbing students' comprehension because the materials might wash over them and have a high potential to be forgotten afterward. It would be better if they initiated to make a short presentation or explanation with their own words or ideas.

\section{DISCUSSIONS}

The result analysis has shown the actual need for developing the content of the English coursebook which encompasses SLA principles. Several factors have already been highlighted. To be specific, extra attention to extensive input is necessary to enhance expected output in L2 learning. The result was 
supported with the analysis of the findings of Guilloteaux (2013) regarding the importance of extensive input (interaction) in materials of English textbooks applied in Korean middle schools that could affect the output. Hence, an extended output is needed. Guilloteaux's research found that three out of five sampled English coursebooks were suitable with SLA principles. Moreover, related to the result of this study that game-based task gained high score in analysis to the reflection of SLA principles, the previous study which had done by Harsono (2015) mentioned that materials should draw attention and attract students to feel ease to learn more, so the tasks could push students to achieve self-investment in learning L2.

The relationship between SLA and L2 pedagogy has always been a growing area of the language learning process. Align with the variable of this research study which emphasized the roles of teachers, Nassaji (2012) researched the same topic by distributing a questionnaire to hundreds of ESL and EFL teachers. The findings showed that most of them believed SLA criteria are beneficial to improve L2 teaching. However, teacher training experience was as important as the aspect of SLA knowledge in the research. Furthermore, Nassaji outlined several crucial points related to the teachers and SLA relationship because teachers had to give some insights about their expectations to gain SLA research and some topics to be investigated. Moreover, this study related to Richards (2006)'s study focused on the impact of SLA research on materials development. Richards emphasized the importance of interaction and meaningful communication to be facilitated in L2 learning with the purpose to reach effective classroom learning so that learners could negotiate the meaning, extend the knowledge of the language, initiate language, and so on. Furthermore, four skills (listening, reading, writing, and speaking) were needed to be presented properly and provide what the learners needed in the English coursebook.

Analysing EFL materials means that it is necessary to understand the needs of teachers and students in the L2 learning process. However, adapting teaching materials, particularly from the textbook, did not always work well. In the classroom, teachers could create their materials to gain the competence for students who wanted to achieve (Harsono, 2015). Speculation that could be made if the textbook did not suitable for learning criteria was that teachers could develop materials by matching the students' needs (Pinter, 2017). A difficult text could be simplified by the teachers to be in line with the students' competency in class.

Limitations of this study were shown in the sample of this study which was one English coursebook "Grow with English" for sixth grade elementary 
students. The result of this study still could not be generalized, yet it could be a reference to conduct similar research with the purpose to develop the content of the English coursebook. The analysis and result of this study were a prior stage in evaluation procedures to determine the extent of whether certain coursebooks were proper enough to support L2 students in the learning process.

\section{CONCLUSION AND SUGGESTION}

The findings of materials analysis can be summed up by analysing the criteria of second language acquisition with the content of the sample coursebook. The writer perceived these certain types of tasks such as game-based tasks and consciousness-raising tasks were proper for language learning and enhance students' motivation to be engaged with L2 since they were the closest to the aspects of SLA principles. It was aligned with the purpose of task-based analysis that was a reference to develop materials' frameworks to gain better input and output for L2 learners. Furthermore, the extent analysis to determine the coursebook supporting the learning process needed to be done thoroughly using in-use evaluation. Overall, this study can be helpful to complete the selection process of the English coursebook for the preliminary phase of the evaluation stages.

Finally, for the next researchers, teachers, English coursebook creators or publishers, and English coursebook policymakers or textbook authorizations, it is expected that this current study can give essential aspects to outline some procedures in SLA principles for materials development that is suitable with the contextual relevance of students' necessity.

\section{REFERENCES}

Anshar, M. R., Emilia, E., \& Damayanti, I. L. (2014). The evaluation of English electronic books for junior high school in Indonesia. Edusentris, 1(3), 289-298.

Aydawati, E. N. (2005). Several considerations in teaching English to children in Indonesian society. TEFLIN International Conference, Universitas Negeri Yogyakarta, Yogyakarta, 6-8.

Ayu, M., \& Indrawati, R. (2019). EFL Textbook Evaluation: The Analysis of Tasks Presented in English Textbook. TEKNOSASTIK. https:/ / doi.org/10.33365/ts.v16i1.87

Bogdan, R. C. (2003). Biklen., SK (2003). Qualitative Research for Education: An Introduction to Theories and Methods, 4.

Cook, V. (1998). Second Language Learning and Language Teaching. College Composition and Communication. https://doi.org/10.2307/358567 
The Perspective of SLA Principles of Materials Analysis on a Thematic English Textbook...

Cunningsworth, A. (1995). Choosing your coursebook. Macmillan.

Dang, T. C. T., \& Seals, C. (2018a). An Evaluation of Primary English

Textbooks in Vietnam: A Sociolinguistic Perspective. TESOL Journal. https:/ / doi.org/10.1002/tesj.309

Dang, T. C. T., \& Seals, C. (2018b). An Evaluation of Primary English Textbooks in Vietnam: A Sociolinguistic Perspective. TESOL Journal, 9(1), 93-113. https:/ / doi.org/10.1002/tesj.309

Ellis, R. (1997). SLA AND LANGUAGE PEDAGOGY: An Educational Perspective. Studies in Second Language Acquisition. https:/ / doi.org/10.1017/S0272263197001058

Ellis, R. (2005). Principles of instructed language learning. System. https:/ / doi.org/10.1016/j.system.2004.12.006

Guilloteaux, M. J. (2013). Language Textbook Selection: Using Materials Analysis from the Perspective of SLA Principles. Asia-Pacific Education Researcher. https:/ / doi.org/10.1007/s40299-012-0015-3

Harsono, Y. M. (2015). DEVELOPING LEARNING MATERIALS FOR SPECIFIC PURPOSES. TEFLIN Journal - A Publication on the Teaching and Learning of English, 18(2). https:/ / doi.org/10.15639/teflinjournal.v18i2/169-179

Ko, C. (2014a). An Investigation of the Communicative Approach Teaching in Primary English Textbooks in Hong Kong and Malaysia: A Search into Communicative Language Teaching (CLT) Textbooks, And How CLT is Applied in Textbooks. International Journal of Education and Literacy Studies. https:/ / doi.org/10.7575/aiac.ijels.v.2n.1p.63

Ko, C. (2014b). An Investigation of the Communicative Approach Teaching in Primary English Textbooks in Hong Kong and Malaysia: A Search into Communicative Language Teaching (CLT) Textbooks, And How CLT is Applied in Textbooks. International Journal of Education and Literacy Studies, 2(1), 63-74.

https://doi.org/10.7575/aiac.ijels.v.2n.1p.63

Littlejohn, A. (2011). The analysis of language teaching materials: Inside the Trojan horse. In Material devolopment in language teaching.

Mares, C. (2003). Writing a coursebook. Developing Materials for Language Teaching, 130-140.

McGrath, I. (2002). Materials evaluation and design for language teaching. Edinburgh University Press.

Mukundan, J., \& Nimehchisalem, V. (2011). An Evaluation of English Language Teaching Courseware in Malaysia. English Language Teaching. https:/ / doi.org/10.5539/elt.v4n3p142

Mukundan, J., Nimehchisalem, V., \& Hajimohammadi, R. (2011).

Developing an English Language Textbook Evaluation Checklist: A Focus Group Study. International Journal of Humanities and Social Science. 
Nakata, Y. (2009). Intrinsic motivation in the EFL school context: A retrospective study of English learning experiences in Japanese elementary schools. Journal of Asia TEFL, 6(4).

Nassaji, H. (2012). The relationship between SLA research and language pedagogy: Teachers' perspectives. Language Teaching Research. https:/ / doi.org/10.1177/1362168812436903

Nikolov, M., \& Djigunović, J. M. (2006). Recent research on age, second language acquisition, and early foreign language learning. Annual Review of Applied Linguistics. https://doi.org/10.1017/S0267190506000122

Pinter, A. (2017). Teaching young language learners. Oxford University Press. Richards, J. (2006). Communicative Language Teaching Today. In CAMBRIDGE UNIVERSITY PRESS.

Sheldon, L. E. (1987). ELT textbooks and materials: Problems in evaluation and development. Modern English Publications.

Tomlinson, B. (2012). Materials development for language learning and teaching. In Language Teaching. https://doi.org/10.1017/S0261444811000528 